\section{Pacific Northwest}

National Laboratory

Operated by Battelle for the

U.S. Department of Energy

\title{
Characterization of Vadose Zone Sediment: Borehole 299-E33-45 Near BX-102 in the B-BX-BY Waste Management Area
}
R. J. Serne
M. J. Lindberg
S. R. Baum
G. V. Last
R. E. Clayton
K. N. Geiszler
G. W. Gee
V. L. LeGore
C. F. Brown
H. T. Schaef
R. D. Orr
M. M. Valenta
D. C. Lanigan
I. V. Kutnyakov
T. S. Vickerman

December 2002

Prepared for CH2M HILL Hanford Group, Inc., and the U.S. Department of Energy under Contract DE-AC06-76RL01830 


\title{
DISCLAIMER
}

This report was prepared as an account of work sponsored by an agency of the United States Government. Neither the United States Government nor any agency thereof, nor Battelle Memorial Institute, nor any of their employees, makes any warranty, express or implied, or assumes any legal liability or responsibility for the accuracy, completeness, or usefulness of any information, apparatus, product, or process disclosed, or represents that its use would not infringe privately owned rights. Reference herein to any specific commercial product, process, or service by trade name, trademark, manufacturer, or otherwise does not necessarily constitute or imply its endorsement, recommendation, or favoring by the United States Government or any agency thereof, or Battelle Memorial Institute. The views and opinions of authors expressed herein do not necessarily state or reflect those of the United States Government or any agency thereof.

\author{
PACIFIC NORTHWEST NATIONAL LABORATORY \\ operated by \\ BATTELLE \\ for the \\ UNITED STATES DEPARTMENT OF ENERGY \\ under Contract DE-AC06-76RL01830
}

Printed in the United States of America
Available to DOE and DOE contractors from the Office of Scientific and Technical Information,
P.O. Box 62, Oak Ridge, TN 37831-0062;
ph: (865) 576-8401
fax: $(865) 576-5728$
email: reports@adonis.osti.gov

Available to the public from the National Technical Information Service, U.S. Department of Commerce, 5285 Port Royal Rd., Springfield, VA 22161 ph: (800) 553-6847 fax: (703) 605-6900

email: orders@ntis.fedworld.gov

online ordering: http://www.ntis.gov/ordering.htm

This document was printed on recycled paper. 


\section{Characterization of Vadose Zone Sediment: Borehole 299-E33-45 Near BX-102 in the B-BX-BY Waste Management Area}
R. J. Serne
G. V. Last
G. W. Gee
H. T. Schaef
D. C. Lanigan
C. W. Lindenmeier

\author{
M. J. Lindberg \\ R. E. Clayton \\ V. L. LeGore \\ R. D. Orr \\ I. V. Kutnyakov
}

S. R. Baum

K. N. Geiszler

C. F. Brown

M. M. Valenta

T. S. Vickerman

December 2002

Prepared for CH2M HILL Hanford Group, Inc., and the U.S. Department of Energy under Contract DE-AC06-76RL01830

Pacific Northwest National Laboratory

Richland, Washington 99352 


\section{Executive Summary}

The overall goal of the Tank Farm Vadose Zone Project, led by CH2M HILL Hanford Group, Inc., is to define risks from past and future single-shell tank farm activities. To meet this goal, CH2M HILL Hanford Group, Inc., asked scientists from Pacific Northwest National Laboratory to perform detailed analyses on vadose zone sediments from within Waste Management Area B-BX-BY. This report is the first in a series of four reports to present the results of these analyses. Specifically, this report contains all the geologic, geochemical, and selected physical characterization data collected on vadose zone sediment recovered from borehole 299-E33-45 installed northeast of tank BX-102.

This report also presents interpretation of the data in the context of the sediment lithologies, the vertical extent of contamination, the migration potential of the contaminants, and the likely source of the contamination in the vadose zone, perched water and groundwater east of the BX tank farm. The information presented in this report supports the Waste Management Area B-BX-BY field investigation report prepared by CH2M HILL Hanford Group, Inc. ${ }^{(a)}$

Overall, the analyses identified common ion exchange and heterogeneous (solid phase-liquid solute) precipitation reactions as two mechanisms that influence the distribution of contaminants within that portion of the vadose zone affected by tank liquor. Significant indications of caustic alteration of the sediment mineralogy or porosity were not observed, but slightly elevated $\mathrm{pH}$ values between the depths of 79 to $141 \mathrm{ft}$ below ground surface (bgs) were observed. X-ray diffraction measurements indicate no evidence of mineral alteration or precipitation resulting from the interaction of the tank liquor with the sediment. However, no samples were studied by scanning electron microscopy, a more sensitive technique for searching for faint evidence of caustic attack.

The analyses do not firmly suggest that the source of the contamination in the groundwater east of the BX tank farm is the 1951 overfill event at tank BX-102. However, evidence is convincing that the fluids from the overfill event are present in the vadose zone sediments at borehole 299-E33-45 to a depth of 170 $\mathrm{ft}$ bgs.

The near horizontally bedded, northeasterly dipping sediment likely caused horizontal flow of the migrating contaminants. At borehole 299-E33-45, there are several fine-grained lenses within the Hanford $\mathrm{H} 2$ unit at 74.5, 120, and $167 \mathrm{ft}$ bgs that likely cause some horizontal spreading of percolating fluids. The 21-ft thick Plio-Pleistocene fine-grained silt/clay unit is also an important horizontal flow conduit as evidenced by the perched water zone between 227 and $232 \mathrm{ft} \mathrm{bgs.}$

The following are the key findings of the detailed characterization of the borehole 299-E33-45 vadose zone sediments. The porewater electrical conductivity shows a two-lobed elevated plume. The shallower lobe, between 24.08 and 36.58 meters (79 and 120 feet) bgs, resides within the middle sand sequence in the Hanford $\mathrm{H} 2$ unit. The shallow lobe appears to pond on top of the fine-grained paleosol at $120 \mathrm{ft}$ bgs. The more concentrated lobe resides between 45.72 and $52.73 \mathrm{~m}$ (150 and $173 \mathrm{ft})$ bgs with the most

(a) Knepp AJ. 2002a. Field Investigation Report for Waste Management Area B-BX-BY. RPP-10098, CH2M HILL Hanford Group, Inc., Richland, Washington. 
concentrated fluid between 150 and $160 \mathrm{ft}$ bgs (within the Hanford $\mathrm{H} 2$ unit) perhaps ponding on the finegrained wet zone (i.e., 167 to $169.8 \mathrm{ft}$ bgs) at the bottom of the Hanford $\mathrm{H} 2$ unit. Thus, the leading edge of the tank overfill plume appears to reside at about $170 \mathrm{ft}$ bgs which is well above the water table at $255 \mathrm{ft}$ bgs.

High nitrate concentrations in borehole 299-E33-45 sediment start at the contact between the Hanford $\mathrm{H} 1$ and $\mathrm{H} 2$ units at 34 feet bgs and extend down into the fine-grained Plio-Pleistocene mud unit (PPlz) and perhaps extend all the way to the water table at $77.7 \mathrm{~m}(255 \mathrm{ft}) \mathrm{bgs}$. The bulk of the water-extractable nitrate is bounded between two thin fine-grained lenses in the $\mathrm{H} 2$ middle sand sequence unit. The upper boundary is the fine-grained lens at $120 \mathrm{ft}$ bgs and lower boundary is the fine-grained $2.5 \mathrm{ft}$-thick lens that forms the bottom of the Hanford $\mathrm{H} 2$ unit at 167 to $170 \mathrm{ft} \mathrm{bgs}$. Nitrate concentrations reach $6150 \mathrm{mg} / \mathrm{L}$ or $\sim 0.1 \mathrm{M}$ at $47.6 \mathrm{~m}(156.2 \mathrm{ft})$ bgs. However, there also appears to be somewhat elevated nitrate throughout the Hanford H3 unit at a fairly constant porewater concentration of $600 \pm 200 \mathrm{mg} / \mathrm{L}$. The nitrate in the $\mathrm{PPlz}$ unit porewater is slightly higher than the nitrate in the $\mathrm{H} 3$ unit. There is a decrease in porewater nitrate in the Plio-Pleistocene gravelly unit (PPlg) down to the capillary fringe zone where nitrate increases to values similar to those found in the groundwater. The nitrate data suggest that the BX-102 overfill fluids might have reached the groundwater. However, an alternate source of nitrate within and below the PPlz could be the nearby cribs and trenches after allowing horizontal transport within the perched water zone.

The significantly elevated uranium-238 concentrations first appear at $73.4 \mathrm{ft}$ bgs in the Hanford $\mathrm{H} 2$ unit sediment just above the first thin lens (one- $\mathrm{ft}$ thick at $74.5 \mathrm{ft}$ bgs). From about $90 \mathrm{ft}$ to $\sim 111 \mathrm{ft}$ bgs, there is little indication that significantly elevated concentrations of uranium are present. Between 111 and $120 \mathrm{ft}$ bgs, the uranium content in the sediment averages about $100 \mathrm{ppm}$. In the thin lens at $120 \mathrm{ft}$ bgs, which may be a paleosol, the uranium concentration is very high (i.e., up to 1,649 ppm in the finest grained material from this sleeve). Below $120 \mathrm{ft}$ bgs down to $145 \mathrm{ft}$ bgs, the uranium content in the sediment is quite high (reaching values between 200 and $500 \mathrm{ppm}$ ). Between 145 and $167.2 \mathrm{ft}$ bgs, in the lower portion of the $\mathrm{H} 2$ middle sand sequence, there are slightly elevated uranium concentrations (between 50 and $200 \mathrm{ppm}$ ). Within the fine-grained lens between 167.2 and $169.8 \mathrm{ft} \mathrm{bgs}$, the uranium concentration increases again to values between 200 and $400 \mathrm{ppm}$. Below in the H3 lower sand sequence and the Plio-Pleistocene sediments, there is no significant indication of elevated uranium in the sediments. The in situ Kd values for uranium are distinctly higher in the PPlz and PPlg strata suggesting that no Hanford processing derived uranium is present (the high $\mathrm{Kd}$ values indicate the presence of only natural uranium that is much less water soluble in these deep vadose zone sediments).

The other major contaminant in the tank overfill fluid is technetium-99. Elevated concentrations of technetium-99 are found in the vadose zone between 120 and $167 \mathrm{ft}$ bgs (within the middle sand sequence of H2). There appears to be a second less concentrated plume of technetium-99 within the contact between the $\mathrm{H} 3$ unit and the PPlz unit (i.e., 220 to $235 \mathrm{ft}$ bgs). Both the acid extractable and water extractable data support this conclusion, however, the water extractable data are of higher quality. There is very good agreement between the technetium-99 concentrations found in the actual porewater and the dilution corrected sediment-water extracts in all regions and lithologies. Further, the technetium-99 concentration in the perched water also agrees with the nearby dilution corrected water extracts. There are obvious elevated concentrations of technetium- 99 in the PPlz but not the PPlg unit down to the water 
table. It is also possible that the technetium-99 in the perched water and groundwater in the vicinity of borehole 299-E33-45 did not come from the overfilling of tank BX-102.

The water extractable cations suggest that an ion-exchange process dominates the major constituent porewater-sediment interactions in the borehole where tank fluid passed by or currently exists. The leading edge of the tank leak plume is enriched in alkaline earth cations that were displaced from the native sediment exchange sites. The interaction of the uranium present in the 1951 tank overfill fluids with the vadose zone sediments appears to include a combination of surface adsorption and discrete solid phase precipitation-dissolution with the precipitated uranium dominating. More mechanistic experiments are discussed in the Science and Technology Project contributions found in Appendix D of the Waste Management Area B-BX-BY field investigation report ${ }^{(\mathrm{a})}$.

Based on a comparison of the depth of penetration of various contaminants and the percentages that are water leachable, it can be stated that uranium migrates slower than technetium- 99 and nitrate. The technetium-99 desorption Kd data are consistently near zero, meaning that the technetium-99 is not interacting with the sediment. Despite the findings that only ten to thirty percent of the uranium is water leachable in 1:1 water extracts over a few days, the uranium desorption $\mathrm{Kd}$ values are still $<3 \mathrm{~mL} / \mathrm{g}$ in the entire zone where the bulk of the tank fluid currently resides.

In summary, the moisture content, $\mathrm{pH}$, electrical conductivity, and the sodium, tritium, and uranium profiles do not suggest that the leading edge of the plume has penetrated below $170 \mathrm{ft}$ bgs. In general, the majority of the ratios of constituents found in the porewater in the Hanford formation sediments are closer to those from the 1951 metals waste solution that escaped tank BX-102 during a cascading accident than to the other possible source, the 1970s BX-101 junction box leaks. The profiles (but not the ratios to other contaminants) of two constituents considered to be mobile, technetium-99 and nitrate, suggest that the leading edge of the plume may have penetrated all the way to groundwater. However, the ratios also suggest there may be other sources of these two mobile contaminants in the deep vadose zone. The perched water is a likely driving force to move fluids from other sources into the borehole environs. The technetium-99 to nitrate ratio for the perched water at $227 \mathrm{ft} \mathrm{bgs}$ is $\sim 1.8 \mathrm{pCi} / \mathrm{mg}$ and for the groundwater at $258.7 \mathrm{ft}$ bgs is $43 \mathrm{pCi} / \mathrm{mg}$. This suggests that there may be a source of water, containing nitrate but not technetium, which is feeding the perched water zone. But this unknown water source has not changed the ratio in the surrounding sediments nor diluted the groundwater that is found only $21 \mathrm{ft}$ deeper. The deep vadose, perched water, and groundwater data at borehole 299-E33-45 do not present a clear picture on what might be occurring in the Plio-Pleistocene unit.

Another unresolved issue is the depth of penetration of uranium and the 1951 tank overfill fluids. Based on the total uranium content in the vadose zone sediments, it is not considered that Hanford derived uranium has penetrated below the fine-grained lens separating the Hanford formation $\mathrm{H} 2$ unit from the H3 unit ( $\sim 170 \mathrm{ft}$ bgs). However, the in situ uranium Kd data suggest that Hanford derived uranium might have penetrated the entire Hanford formation down to the Plio-Pleistocene mud unit at $220 \mathrm{ft}$ bgs. 


\section{Acronyms and Abbreviations}

\begin{tabular}{|c|c|}
\hline ASA & American Society of Agronomy \\
\hline ASTM & American Society for Testing and Materials \\
\hline bgs & below ground surface \\
\hline $\mathrm{EC}$ & electrical conductivity \\
\hline EPA & $\begin{array}{l}\text { Environmental Protection Agency (United States federal government regulatory } \\
\text { organization) }\end{array}$ \\
\hline FIR & Field Investigation Report \\
\hline $\mathrm{g}$ & gravitational constant $\left(980 \mathrm{~cm}^{2} / \mathrm{s}\right)$ \\
\hline GEA & gamma energy analysis \\
\hline GPS & global positioning system \\
\hline $\mathrm{HCl}$ & hydrochloric acid \\
\hline HPGe & High-Purity Germanium \\
\hline IC & ion chromatography \\
\hline $\mathrm{ICP}$ & $\begin{array}{l}\text { inductively coupled plasma (also called inductively coupled plasma - optical emission } \\
\text { spectroscopy }\end{array}$ \\
\hline ICP-MS & inductively coupled plasma mass spectrometer \\
\hline ICP-OES & inductively coupled plasma - optical emission spectroscopy \\
\hline $\mathrm{Kd}$ & distribution coefficient or sorption partition coefficient in units of $\mathrm{mL} / \mathrm{g}$ \\
\hline KUT & potassium, uranium, and thorium \\
\hline MSL & mean sea level \\
\hline PNNL & Pacific Northwest National Laboratory \\
\hline PPlc & Plio-Pleistocene caliche layer \\
\hline PPlg & Plio-Pleistocene gravelly sand or sandy gravel unit \\
\hline PPlz & Plio-Pleistocene mud unit \\
\hline QA & quality assurance \\
\hline QC & quality control \\
\hline RCRA & Resource Conservation and Recovery Act \\
\hline REDOX & $\begin{array}{l}\text { Reduction Oxidation Process (the second fuel reprocessing process used at the Hanford } \\
\text { Site to extract plutonium) }\end{array}$ \\
\hline SEM & scanning electron microscope \\
\hline TEM & transmission electron microscopy \\
\hline UFA & unsaturated flow apparatus (ultracentrifuge for squeezing porewater out of sediment) \\
\hline UV & ultraviolet \\
\hline WMA & Waste Management Area \\
\hline XRD & X-ray diffraction \\
\hline $\mathrm{XRF}$ & x-ray fluorescence (a technique to measure total element mass in solids) \\
\hline
\end{tabular}




\section{Contents}

Executive Summary .............................................................................................

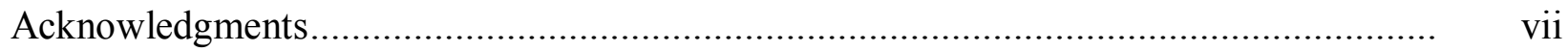

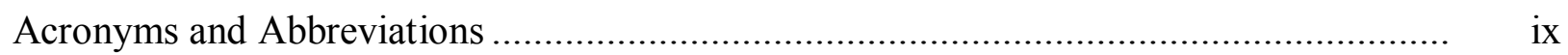

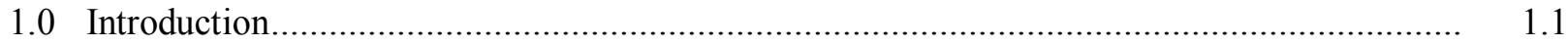

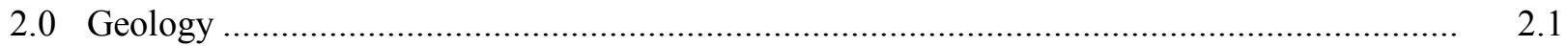

2.1 Geologic Setting of the 241-BX Tank Farm ............................................................. 2.1

2.2 Drilling and Sampling of Well 299-E33-45 .............................................................. 2.1

2.3 Geophysical Logging....................................................................................... 2.9

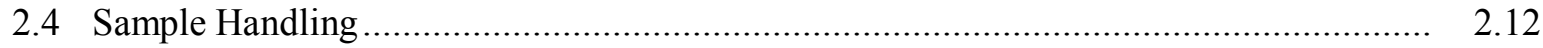

2.5 Sub-Sampling and Geologic Description ………………........................................ 2.13

2.6 Geology of Well 299-E33-45 ........................................................................ 2.14

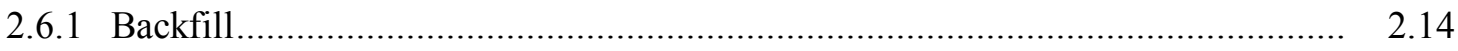

2.6.2 Hanford Formation .................................................................................... 2.15

2.6.3 Hanford /Plio-Pleistocene/Ringold (?) Unit ………………………………….. 2.21

2.7 Historic Groundwater Levels ............................................................................. 2.27

3.0 Geochemical Method and Materials................................................................................ 3.1

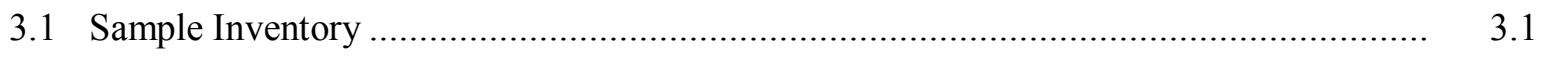

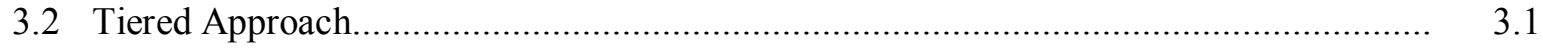

3.3 Materials and Methods ................................................................................... 3.2

3.3.1 Moisture Content ………………………………………………..... 3.2

3.3.2 1:1 Sediment-to-Water Extracts …………………………………………... 3.2

3.3.3 Porewater, Perched and Groundwater Composition ............................................. 3.4

3.3.4 Radioanalytical Analysis ............................................................................ 3.4

3.3.5 Carbon Content of Sediment ............................................................................ $\quad 3.5$

3.3.6 8 M Nitric Acid Extract............................................................................. 3.5

3.3.7 Elemental Analysis ............................................................................. 3.6

3.3.8 Particle Size Distribution ........................................................................ 3.6

3.3.9 Particle Density....................................................................................... 3.6

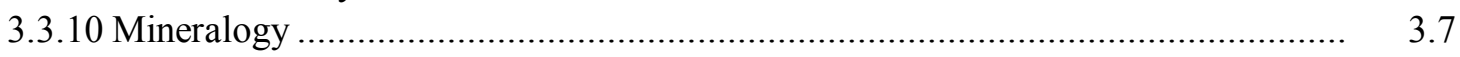

3.3.11 Water Potential (Suction) Measurements .......................................................... 3.8

3.3.12 Uranium Desorption Experiment .................................................................. 3.9

4.0 Results and Discussion .......................................................................................... 4.1

4.1 Moisture Content ........................................................................................ 4.1

4.2 1:1 Sediment-to-Water Extracts ........................................................................... 4.4

4.2.1 pH and Electrical Conductivity …………………………………………... 4.5

4.2.2 Water Extract and Porewater Compositions...................................................... 4.10

4.2.3 Porewater Solute Ratios .......................................................................... 4.37

4.3 Radionuclide Content in Vadose Zone Sediment......................................................... 4.51

4.3.1 Gamma Energy Analysis......................................................................... 4.51 
4.3.2 Uranium Content in Sediment ............................................................. 4.58

4.3.3 Technetium-99 Content in the Vadose Zone Sediments .................................. 4.59

4.3.4 Tritium Content in Vadose Zone Sediments .................................................... 4.59

4.3.5 Other Radionuclides............................................................................. 4.60

4.4 Total Cyanide Content of the Vadose Zone Sediments ............................................. 4.70

4.5 Total Carbon, Calcium Carbonate, and Organic Carbon Content of Vadose Zone

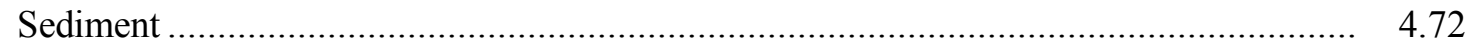

4.6 $8 \mathrm{M}$ Nitric Acid Extractable Amounts of Selected Elements......................................... 4.74

4.7 Sediment Total Oxide Composition .......................................................................... 4.78

4.8 Particle Size Measurements on Vadose Zone Sediment.............................................. 4.79

4.9 Particle Density of Bulk Sediment ..................................................................... 4.80

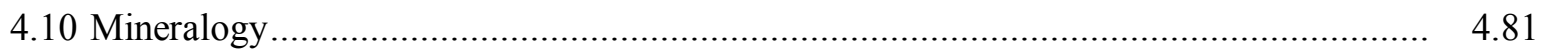

4.11 Matric Suction Potential Measurements .................................................................... 4.84

4.12 Perched Water and Groundwater Analyses ........................................................ 4.91

5.0 Uranium Leach/Desorption Tests............................................................ 5.1

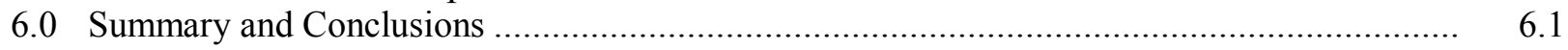

6.1 Conceptual Model of the Geology at Borehole 299-E33-45 .......................................... 6.1

6.2 Vertical Extent of Contamination................................................................................ 6.2

6.3 Detailed Characterization to Elucidate Controlling Geochemical Processes................... 6.6

6.4 Estimates of Sorption-Desorption Values.................................................................. 6.8

6.5 Source of Contamination in the Deep Vadose Zone, Perched Water, and Groundwater .. 6.10

6.6 Other Characterization Observations........................................................................ 6.12

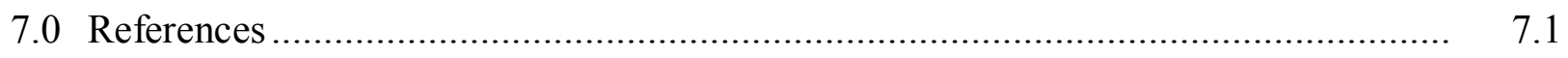

Appendix A - Core Descriptions …......................................................................... A.1

Appendix B - Core Samples from Borehole 299-E33-45 ...................................................... B. 1

Appendix C - Particle Size Data from Nearby Boreholes ................................................... C. 1

Appendix D - X-Ray Diffraction Patterns for Selected Core Samples ..................................... D.1 


\section{Figures}

2.1. Generalized, Composite Stratigraphy for the Late Cenozoic Sediments Overlying the Columbia River Basalt Group Beneath the 241-B and 241-BX Tank Farms .................................... 2.2

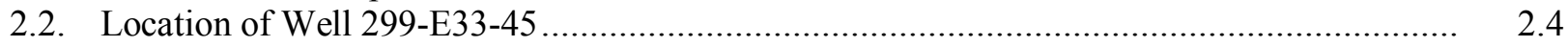

2.3. Generalized Borehole Log for Well 299-E33-45 .......................................................... 2.11

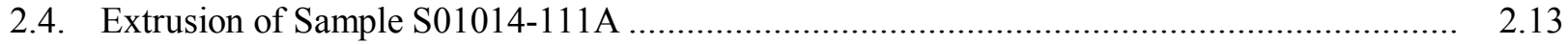

2.5. Sediment Classification Scheme (Modified after Folk 1968) and Grain Size Nomenclature). 2.14

2.6. Example of the Gravel Dominated Hanford H1 Unit from Sample S01014-6A Collected at a Depth of 6.3 to $6.4 \mathrm{~m}(20.6$ to $21.1 \mathrm{ft})$

2.7. Example of the H2 Upper Sand Sequence in Sample S01014-16C, Collected at a Depth of $12.6-12.7 \mathrm{~m}(41.3-41.8 \mathrm{ft})$

2.8. Contact Between H2 Upper Sand Squence and Underlying Muddy Very Fine to Fine Sand Layer, as Observed in Sample S01014-34C, Collected at a Depth of 22.7 to $22.8 \mathrm{~m}$ (74.4 to $74.9 \mathrm{ft})$

2.9. Lower Contact of the Muddy Very Fine to Fine Sand Layer in Sample S01014-34A at a Depth of 23 to $23.1 \mathrm{~m}(75.4$ to $75.9 \mathrm{ft})$.

2.10. Coarse to Very Coarse Sand of the Middle Sand Sequence from Sample S-101014-35B at a Depth of 23.6 to $23.7 \mathrm{~m}(77.4$ to $77.9 \mathrm{ft})$

2.11. Contact Between Coarse Sand and Medium Sand Strata in the Middle Sand Sequence from Sample S-01014-44C at a Depth of 30.1 to $30.2 \mathrm{~m}(98.8$ to $99.3 \mathrm{ft})$.

2.12. Thin Weak Paleosol(?) Observed in Sample S01014-54C at a Depth of 36.5 to $36.6 \mathrm{~m}$ $(119.6$ to $120.1 \mathrm{ft})$....

2.13. Fine to Very Fine Sand and Poorly Sorted Medium Sand Sequence Observed in Sample S01014-82B at a Depth of 51.2 to $51.3 \mathrm{~m}(167.9$ to $168.4 \mathrm{ft})$

2.14. Poorly Sorted Medium Sand in Contact with the Silty Very Fine Sand Layer in Sample S01014-83D at a Depth of 51.6 to $51.7 \mathrm{~m}$ (169.3 to $169.8 \mathrm{ft})$....

2.15. Coarse to Medium Sand of the Lower Sand Sequence Observed in Sample S01014-88C at a Depth of 55.0 to $55.1 \mathrm{~m}(180.4$ to $180.9 \mathrm{ft})$

2.16. Gravelly (Mostly Fine to Very Fine Pebble) Coarse to Medium Sand in Sample S01014-88A at a Depth of 55.3 to $55.4 \mathrm{~m}$ (181.4 to $181.9 \mathrm{ft})$

2.17. Moderate to Strongly Cemented Coarse to Medium Sand in Sample S01014-104Dat a Depth of 63.9 to $64 \mathrm{~m}$ (209.7 to $209.2 \mathrm{ft})$.

2.18. Contact Beneath Upper Sand and Lower Mud (Silt) Strata with in the Silt Facies of the $\mathrm{H} / \mathrm{PP} / \mathrm{R}$ (?) Unit in Sample S01014-110C at a Depth of 66.5 to $66.6 \mathrm{~m}$ (218.2 to $218.7 \mathrm{ft}$ )

2.19. Mud (Silt) from the Silty Facies of the H/PP/R (?) Unit Encountered in Sample S01014-111A at a Depth of 67.5 to $67.6 \mathrm{~m}(221.5$ to $222.0 \mathrm{ft})$.

2.20. Muddy Sandy Gravel Encountered in Sample S01014-122 D at a Depth of 73.5 to $73.6 \mathrm{~m}$ (240.1 to $240.6 \mathrm{ft}$ )

2.21. Sandy Gravel from Sample S01014-129B at a Depth of 77.1 to $77.2 \mathrm{~m}$ (252.9 to $253.4 \mathrm{ft})$...

4.1. $\mathrm{pH}$ and Electrical Conductivity for Calculated (from sediment-to-water extracts) and Actual Porewaters for Borehole 299-E33-45 Sediment

4.2a. Major Anions Calculated (from sediment-to-water extracts) and Actual Porewaters from Borehole 299-E33-45

4.2b. 1:1 Sediment-to-Water Extract, Actual Porewater, Perched Water, and Groundwater Minor Anion Contents for Fluids Derived from Borehole 299-E33-45 
4.3. Cations Calculated (from Sediment-to-Water Extracts) and Actual Porewaters for Borehole 299-E33-45 Sediment.

4.4. Pore Fluid Concentrations of Aluminum, Iron, Silicon, and Manganese (Calculated from Sediment-to-Water Extracts) and Actual Porewaters for BX-102 Borehole Sediment......

4.5. Trace Metals Pore Fluid (Calculated from Sediment-to-Water Extracts) and Actual Porewaters for BX-102 Borehole Sediment ....

4.6. Porewater Ratios of Key Constituents in Bismuth Phosphate Waste to Chloride

4.7. Porewater Ratios for Key Bismuth Phosphate Waste Constituents to Nitrate and Technetium (Mobile Species).

4.8. Porewater Ratios for Key Bismuth Phosphate Constituents versus Each Other.

4.9. Uranium-238 and Potassium-40 Content in Sediment from Borehole 299-E33-45

4.10. Three Independent Methods of Estimating Uranium-238 in Vadose Sediment (pCi/g)

4.11. Concentration of Uranium-238 in BX-102 Borehole Sediment that is Water or Acid Extractable

4.12. Uranium Desorption Kd Values

4.13. Concentration of Technetium-99 (pCi/g) and In Situ Kd Values (mL/g) in Vadose Zone Sediments from Borehole 299-E33-45.

4.14. Comparison Between Acid and Water Extractable Concentrations of Major Cations

4.15. Comparison Between Acid and Water Extractable Concentrations of Barium, Aluminum, Silicon, and Iron.

4.16. XRD Tracing of Bulk Sediment Sample 11A (221.8 ft bgs) Along with a Standard Reference Pattern for Quartz.

4.17. XRD tracings of preferentially oriented clay slides taken of sample $111 \mathrm{~A}(221.8 \mathrm{ft} \mathrm{bgs}) \ldots \ldots$.

4.18. Matric Water Potential Measured by Filter Paper Technique on Core Samples from Borehole 299-E33-45

4.19. Matric Water Potential Measured by Filter Paper Technique on Core Samples from Borehole 299-E33-338 Located Outside the Southeast Perimeter of the B Tank Farm.

4.20. Values for Major Anions in the Perched and Groundwater Compared to Calculated Porewater from the Deep Vadose Zone

4.21. Minor Anion Composition in the Perched and Groundwater Compared to Calculated Porewater from the Deep Vadose Zone

4.22. $\mathrm{pH}$ and Electrical Conductivity Values for the Perched and Groundwater Compared to Calculated Porewater from the Deep Vadose Zone....

5.1. Uranium Solution Concentrations as Function of Time.

5.2. Effluent $\mathrm{pH}$ for the Leachates in Contact with Contaminated Sediment

5.3. Cumulative Percentage Uranium Leached from the Contaminated Sediments versus Contact Time

5.4. Desorption Kd Values for the Uranium Contaminated Sediments Leached with Simulated Porewater and 0.02 M Sodium Bicarbonate Solution as a Function of Time. 


\section{Tables}

2.1. Stratigraphic Terminology Used in this Report for the Vadose Zone Beneath the BX Tank Farm

2.2. Depth of Split-Spoon Samples.

2.3. Depth of Composite and Split-Spoon Shoe Grab Samples .

3.1. Chemical Composition of Simulated Vadose Zone Porewater Solution............................ 3.10

4.1. Moisture Content of Sediment from Borehole 299-E33-45 .......................................... 4.2

4.2. Water Extract $\mathrm{pH}$ and Electrical Conductivity Values..................................................... 4.6

4.3. Comparison of Actual Porewater $\mathrm{pH}$ and Electrical Conductivity with Dilution-Corrected 1:1 Water Extract Values

4.4. Anion Content of Water Extracts of Borehole BX-102 Sediment.

4.5. Comparison of Calculated with Actual Porewater Anion Concentrations for Borehole 299-E33-45 Vadose Zone Sediment ....

4.6. Calculated Porewater Cation Composition from Water Extracts of Vadose Zone Sediment from Borehole 299-E33-45..

4.7. Comparison of Actual to Calculated (from 1:1 water extracts) Porewaters-Cations .............

4.8. Comparison of ICP Sulfur and Phosphorous as Sulfate and Phosphate with IC Sulfate and Phosphate (mg/L) for Dilution Corrected Water Extracts....

4.9. Calculated Porewater Trace Metal Composition for Water Extracts of Sediment from Borehole 299-E33-45.

4.10. Comparison of Actual to Calculated (from 1:1 Water Extracts) Porewaters-Trace Metals.... 4.35

4.11. Ratio of the Mobile Contaminants in Bismuth Phosphate Metals Waste to Chloride Found in Dilution Corrected 1:1 Water to Sediment Extracts.

4.12. Ratio of the Mobile Contaminants in Bismuth Phosphate Metals Waste to Chloride Found in Actual Porewaters, Perched Water, and Groundwater ...

4.13. Ratio of Main Bismuth Phosphate Constituents in Dilution Corrected 1:1 Water Extracts Versus Each Other .....

4.14. Ratio of Main Mobile Bismuth Phosphate Constituents in Porewater, Perched Water, and Groundwater Versus Each Other .....

4.15. Gamma Energy Analysis of Vadose Zone Sediment.

4.16. Comparison of Uranium Contents in Vadose Sediments from Borehole 299-E33-45...

4.17. Calculated In Situ Kd Values $(\mathrm{mL} / \mathrm{g})$ for Uranium in the Vadose Zone Sediments from Borehole 299-E33-45.

4.18. Technetium-99 Content and In Situ Kd (mL/g) in Sediment (based on 8 M Nitric Acid Extracts and Water Extracts).....

4.19. Tritium Content in Water Extracts, Perched Water and Groundwater $(\mathrm{pCi} / \mathrm{L})$.....................

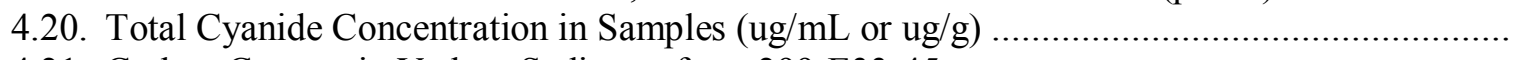

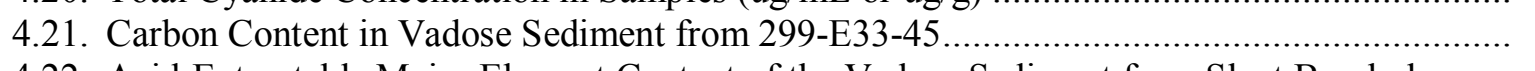

4.22. Acid-Extractable Major Element Content of the Vadose Sediment from Slant Borehole ........

4.23. Total Composition of the Vadose Zone Sediment from 299-E33-45 Percent Weight as Oxides

4.27. Semiquantitative Analysis of the Clay Fraction from Borehole 299-E33-45 in Weight Percent...... 
4.28. Matric Potential Data for Borehole 299-E33-45 Sediments as a Function of Depth ............. 4.86

4.29. Composition of Perched and Groundwater Taken from Borehole 299-E33-45 ................... 4.94

5.1. Uranium Solution Concentrations versus Time.......................................................... 5.2

5.2. Ending $\mathrm{pH}$ Values for the Uranium Leach Solutions................................................ 5.3

5.3. Electrical Conductivity of the Uranium Leach Solutions.................................................. 5.4

5.4. Cumulative Percentage of Uranium Leached from Selected Contaminated Sediments from Borehole 299-E33-45

5.5. Desorption Kd Value for Uranium Leached from Selected Contaminated Sediments from Borehole 299-E33-45 